\title{
Carbon dynamics in no-till soil due to the use of industrial organic waste and mineral fertilizer ${ }^{1}$
}

\author{
Dinâmica do carbono do solo em plantio direto devido ao uso de resíduos orgânicos \\ industriais e fertilizante mineral
}

\author{
Jucimare Romaniw ${ }^{2 *}$, João Carlos de Moraes Sá ${ }^{3}$, Alessandra Aparecida Padilha ${ }^{4}$, Fabrícia da Silva Ramos ${ }^{4}$, \\ Guilherme Eurich ${ }^{4}$ e Pamela Thaísa Bressan ${ }^{4}$
}

\begin{abstract}
The use of organic waste from industrial processes in agriculture is a strategy not only for improving soil properties but also for promoting the utilization of recycled nutrients by market crops and for reducing environmental impact. The aim of this study was to evaluate the effects of using organic waste from pork and poultry slaughterhouses (OWS) applied alone or in combination with mineral fertilizer (MF) on the dynamics of soil organic matter (SOM) compartments. The experimental design adopted was that of completely randomized blocks with six treatments and three replicates. The treatments consisted of a general control (T1) without the addition of MF and OWS, the application of MF alone at $100 \%$ of the recommended fertilizer levels for the crops (T2),the application of OWS alone at a fixed dose of $2 \mathrm{Mg} \mathrm{ha}^{-1}$ (T3), and the following three combinations of MF and OWS: $75 \% \mathrm{MF}+25 \%$ OWS (T4); 50\% MF + 50\% OWS (T5); and 25\% MF + 75\% OWS (T6). The application of OWS promoted increase in the labile fractions extracted by potassium permanganate (C-OXP) and hot water (C-HW) compared with using MF alone. Using OWS in the combination of 50\% MF + 50\% OWS increased the content and stock of total organic carbon (TOC) in the $0-20 \mathrm{~cm}$ layer and of particulate organic $\mathrm{C}$ (POC) and C-OXP in the $0-5 \mathrm{~cm}$ layer.
\end{abstract}

Key words: Organic matter compartments. Total organic carbon.

\begin{abstract}
RESUMO - A utilização de resíduos orgânicos provenientes de processos industriais na agricultura constitui-se em uma estratégia não apenas para melhoria dos atributos do solo, como também, para proporcionar aproveitamento dos nutrientes reciclados pelas culturas econômicas e redução no impacto ambiental. O objetivo desse trabalho foi avaliar a contribuição do uso de resíduos orgânicos de abatedouros (ROA) de aves e suínos aplicados isolados ou em combinação ao fertilizante mineral (FM) na dinâmica dos compartimentos da matéria orgânica do solo (MOS). O delineamento experimental adotado foi em blocos completamente casualizados com seis tratamentos distribuídos e três repetições. Os tratamentos constituíram-se de um controle geral (T1) sem adição de FM e ROA, e aplicação isolada de FM constituindo o suprimento de $100 \%$ da recomendação de adubação para as culturas (T2), aplicação isolada de ROA fixada na dose $2 \mathrm{Mg} \mathrm{ha}^{-1}$ (T3) e três combinações de FM e ROA, sendo: $75 \%$ de $\mathrm{FM}+25 \%$ de ROA (T4); 50\% de FM + 50\% de ROA (T5); e, 25\% de FM + 75\% de ROA (T6). A aplicação de ROA promoveu o aumento das frações lábeis (C-OXP e C-AQ) em relação ao uso isolado do FM. O uso do ROA na combinação de 50\% de $\mathrm{FM}+50 \%$ de ROA aumentou o conteúdo e o estoque de carbono orgânico total (COT) na camada de 0-20 cm e do C orgânico particulado (COP) e C lábil extraído com permanganato (C-OXP) na camada de 0-5 cm.
\end{abstract}

Palavras-chave: Carbono orgânico total. Frações da matéria orgânica.

\footnotetext{
DOI: $10.5935 / 1806-6690.20150029$

*Autor para correspondência

${ }^{1}$ Recebido para publicação em 14/03/2014; aprovado em 07/05/2015

Parte da Dissertação de Mestrado do primeiro autor apresentada Programa de Pós-Graduação em Agronomia da Universidade Estadual de Ponta Grossa/UEPG

${ }^{2}$ Departamento de Agronomia, Universidade Estadual de Ponta Grossa/UEPG, Campus Uvaranas, Av. General Carlos Cavalcanti, 4748, Campus Central, Praça Santos Andrade 1, Ponta Grossa-PR, Brasil, 84.030-900 ju.romaniw @ gmail.com

${ }^{3}$ Departamento de Ciência do Solo e Engenharia Agrícola, Universidade Estadual de Ponta Grossa, Ponta Grossa-PR, Brasil, jcmsa@uepg.br

${ }^{4}$ Departamento de Agronomia, Universidade Estadual de Ponta Grossa, Ponta Grossa-PR, Brasil, alessandra_agrop@ig.com.br, fabisr1984@ hotmail.com, guilhermeeurich@ hotmail.com, pamelabressan@gmail.com
} 


\section{INTRODUCTION}

The annual growth of pork production in developing countries was estimated to reach $1.5 \%$ by the end of 2013 , and the growth rate of poultry production was estimated to reach $3.64 \%$ by 2020 (FOOD AND AGRICULTURE ORGANIZATION OF THE UNITED NATIONS, 2010). Brazil is the world's fourth largest producer of pork and the third largest poultry producer (ASSOCIAÇÃO BRASILEIRA INDÚSTRIA PRODUTORA E EXPORTADORA DE CARNE SUÍNA, 2011; UNITED STATES DEPARTMENT OF AGRICULTURE, 2010). In this context, the State of Paraná produced 2.9 million $\mathrm{Mg}$ of poultry and $629,000 \mathrm{Mg}$ of slaughtered pork in 2011, making it the largest poultry producer and the fourth largest pork producer in the country (INSTITUTO BRASILEIRO DE GEOGRAFIA E ESTATÍSTICA, 2010). In Brazil, nearly 3 to 4 million $\mathrm{Mg}$ of animal waste are produced that are not consumable by humans (BELLAVER, 2003). It is estimated that $32 \%$ of poultry, $38 \%$ of pork, $46 \%$ of cattle and $48 \%$ of sheep are considered waste and destined for recycling processes. Of these, $75-80 \%$ will be reused in the manufacture of livestock feed, and 20-22\% will remain as organic waste, generally disposed of in the environment. The National Environment Policy (Política Nacional do Meio Ambiente - PNMA - Law 6,938, 1981) calls for the management of industrial organic waste to prevent, protect from, and reduce pollution and to simultaneously restore the quality of the environment by recycling these wastes.

The disposal of waste in sanitary landfills and dumps is not the best solution and does not meet most of the requirements for the maintenance of environmental quality. Among the alternatives for recycling industrial organic waste, their use as a biofertilizer in agriculture is the most environmentally friendly option (NOGUEIRA, et al., 2012). A number of studies have shown that various types of soil management can significantly affect the labile forms of total organic carbon, and the magnitude of these effects depends on the regional climate, soil type, waste management practices, and crop rotation (BANGER et al., 2010; RUDRAPPA et al., 2006). Thus, analyses of the processes and mechanisms of soil $\mathrm{C}$ sequestration should be related to soil attributes, specifying the cultivation systems and factors that govern the accumulation of $\mathrm{C}$.

The benefits of using industrial organic waste as organic fertilizer have been well reported, including increased microbial activity and organic carbon content that result in the improvement of soil physical properties and in the increased productive potential of crops (JIANG et al., 2006; LEITE et al., 2003). However, there are few studies that show the effects of applying this type of waste on the labile forms of $\mathrm{C}$ and the potential for recovering the quality of agricultural soils (JIANG et al., 2006).
Soil organic matter (SOM) is highly diverse in terms of oxidation state, chemical composition, size, recalcitrance, and chemical and physical protection. Since Christensen et al. (1992) proposed a non-destructive approach for the study of SOM using methods for separating $\mathrm{C}$ into compartments by size or oxidation states, there have been significant advances in the knowledge of $\mathrm{C}$ dynamics. Physical fractionation methods using dense liquids or wet sieving has allowed for the quantification of the impacts of management systems (BAYER; MIELNICZUK; MARTINNETO, 2000; BAYER et al., 2001; SÁ et al., 2001).

Particle-size fractionation of SOM proposes division into three fractions: a light fraction measuring 250 to $2000 \mathrm{~m}$; a particulate fraction measuring 53 to $250 \mathrm{~m}$; and a soil mineral-associate fraction measuring $<53 \mathrm{~m}$. The soil mineral-associate fraction is most stable, showing no immediate sensitivity to changes in soil management practices; therefore, it constitutes the medium and longterm carbon stock. The labile fraction of $\mathrm{C}$ contains $\mathrm{C}$ extracted using hot water and oxidized by permanganate and the particulate fraction of SOM. This fraction responds rapidly to soil management systems, especially to the input of organic material in the soil and tillage operations that alter the water and air flows in the soil (BAYER et al., 2002).

The hypothesis proposed for this study is based on the principle that the accumulation of $\mathrm{C}$ in soil results from creating a continuous flow of $\mathrm{C}$ from the labile fractions supporting the formation of stable $\mathrm{C}$ compartments. Consequently, favorable conditions for an increase in grain production are generated in response to improved chemical, physical and biological properties. In this context, the specific objective of this study was to assess the carbon dynamics in soil carbon compartments in response to the application of biofertilizers alone or in combination with mineral fertilizers within 5 years of adoption of a no-till system.

\section{MATERIALS AND METHODS}

\section{Description of the study site}

The study was conducted in the municipality of Ponta Grossa, Paraná, whose geographical coordinates are $25^{\circ} 05^{\prime} 27^{\prime \prime} \mathrm{S}$ and $50^{\circ} 3.4^{\prime} 53^{\prime}$ ' $\mathrm{W}$. The average elevation in the study area is $990 \mathrm{~m}$ above sea level, and the climate is characterized as humid subtropical, mesothermal, $\mathrm{Cfb}$ (Koeppen classification). The average annual maximum temperature is $24.1{ }^{\circ} \mathrm{C}$ (44-year series) (INSTITUTO AGRONÔMICO DO PARANÁ, 2010), and the average annual minimum temperature is $13.3^{\circ} \mathrm{C}$. The average annual rainfall is $1,545 \mathrm{~mm}$, distributed regularly throughout the year without any dry periods. 
The soil in the experimental area was classified as Haplic Cambisol (Inceptisol), with medium texture in the 0-20 cm layer and sand, silt, and clay levels of 665, 89, and $247 \mathrm{~g} \mathrm{~kg}^{-1}$, respectively. Prior to the experiment, soil samples were collected at depths of 0-5, 5-10, 10-20, and $0-20 \mathrm{~cm}$ to assess soil fertility (Table 1 ).

The organic fertilizer used in the experiment, hereafter called organic waste from a slaughterhouse (OWS), consisted of residues originating from the slaughter of poultry and pork (e.g., viscera, cartilage, beaks and feathers of birds, blood, excrement, hair, pork skin and feet, and birds that died in transport). In short, the waste was subjected to heat treatment in which it passed through a tubular reactor at high pressure and a temperature of approximately $120^{\circ} \mathrm{C}$ for the sterilization of the waste and for the separation of the oil and meal for use in feed. After cooling, the OWS was sent to a location for composting, and then the waste was finally sent to the final product storage area, where it exhibited the mean composition described below (Table 2).

Table 1 - Chemical properties of the soil from the experimental area before starting the experiment in June 2009 in a Haplic Cambisol ${ }^{1}$, Ponta Grossa - PR

\begin{tabular}{|c|c|c|c|c|c|c|c|c|c|}
\hline Prof. (cm) & $\mathrm{pH}^{(2)}$ & $\mathrm{H}+\mathrm{Al}^{+3(3)}$ & $\mathrm{Al}^{+3(4)}$ & $\mathrm{Ca}^{+2(5)}$ & $\mathrm{Mg}^{+2(5)}$ & $\mathrm{K}^{+(4)}$ & $\mathrm{CEC}^{(6)}$ & $\mathrm{P}^{(5)}$ & $\mathrm{C}^{(7)}$ \\
\hline $\mathrm{Cm}$ & & \multicolumn{6}{|c|}{ 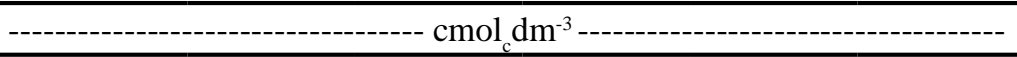 } & \multicolumn{2}{|c|}{$\mathrm{mg} \mathrm{dm}^{3} \mathrm{~g} \mathrm{~kg}^{-1}$} \\
\hline $0-5$ & 4.86 & 6.62 & 0.09 & 3.58 & 1.63 & 0.36 & 12.2 & 52.0 & 22.3 \\
\hline $5-10$ & 4.70 & 7.27 & 0.17 & 1.47 & 1.47 & 0.25 & 10.4 & 40.1 & 14.3 \\
\hline $10-20$ & 4.60 & 7.15 & 0.21 & 2.23 & 1.24 & 0.19 & 10.8 & 30.7 & 11.3 \\
\hline $0-20$ & 4.58 & 7.18 & 0.19 & 2.51 & 1.29 & 0.24 & 11.2 & 38.1 & 14.8 \\
\hline
\end{tabular}

The numbers in the rows represent the average of ten points sampled in the experimental area. ${ }^{1}$ Soil Taxonomy 11 ed., $2010 ;{ }^{2} \mathrm{pH} \mathrm{extracted} \mathrm{by} \mathrm{CaCl}_{2}$ (1:2.5); ${ }^{3}$ Extracted with $0.5 \mathrm{~mol} \mathrm{~L}^{-1}$ calcium acetate, $\mathrm{pH} 7.0$, and measured by titration; ${ }^{4}$ Extracted with $1 \mathrm{~mol} \mathrm{~L}^{-1}$ potassium chloride and measured by titration; ${ }^{5}$ Extracted with Melich-1 solution; ${ }^{6} \mathrm{CEC}$ : cation exchange capacity at $\mathrm{pH} 7$; and ${ }^{7}$ Average of nine points analyzed using dry combustion

Table 2 - Chemical analysis of organic waste used in the experiment, originating from poultry and pork slaughterhouses

\begin{tabular}{llc}
\hline \multicolumn{1}{c}{ Attributes } & Unit & Content $^{(1)}$ \\
\hline $\mathrm{pH}^{(2)}$ & & 6.70 \\
\hline Moisture $\left(60-65^{\circ} \mathrm{C}\right)$ & $\mathrm{g} \mathrm{kg}^{-1}$ & 36.0 \\
Total organic carbon & 321 \\
Total nitrogen $^{(3)}$ & $\mathrm{g} \mathrm{kg}^{-1}$ & 47.2 \\
Phosporus $^{(4)}$ & $\mathrm{g} \mathrm{kg}^{-1}$ & 10.5 \\
Potassium $^{(5)}$ & $\mathrm{g} \mathrm{kg}^{-1}$ & 9.50 \\
Sulfur $^{(6)}$ & $\mathrm{g} \mathrm{kg}^{-1}$ & 3.50 \\
Calcium $^{(5)}$ & $\mathrm{g} \mathrm{kg}^{-1}$ & 109 \\
Magnesium $^{(5)}$ & $\mathrm{g} \mathrm{kg}^{-1}$ & 4.10 \\
Boron $^{(7)}$ & $\mathrm{g} \mathrm{kg}^{-1}$ & 18.1 \\
Cooper $^{(5)}$ & $\mathrm{mg} \mathrm{kg}^{-1}$ & 51.2 \\
Iron $^{(5)}$ & $\mathrm{mg} \mathrm{kg}^{-1}$ & 15341 \\
Manganese $^{(5)}$ & $\mathrm{mg} \mathrm{kg}^{-1}$ & 1086 \\
Mo $^{(5)}$ & $\mathrm{mg} \mathrm{kg}^{-1}$ & 3.1 \\
Sodium $^{(5)}$ & $\mathrm{mg} \mathrm{kg}^{-1}$ & 3110 \\
Zinc $^{(5)}$ & $\mathrm{mg} \mathrm{kg}$ & 90.5 \\
\hline
\end{tabular}

${ }^{1}$ Average of five samples collected from the residue mound after processing; ${ }^{2} \mathrm{pH}$ in water; ${ }^{3}$ Extracted by dry combustion; $;{ }^{4}$ Colorimetric method; ${ }^{5}$ Determined by atomic absorption spectrophotometry; ${ }^{6}$ Barium chloride spectrophotometric method; and ${ }^{7}$ Extracted using the azomethine-H spectrophotometric method 
The experiment had a randomized block design with six treatments and three replicates, as follows: (i) General control without mineral fertilizer (MF) and without organic waste from slaughterhouses (OWS), henceforth referred to as $\mathrm{T} 1$; (ii) the application of MF alone to provide $100 \%$ of the recommended fertilizer levels (following the recommendations for the crops and the soil analysis of the ABC Foundation), henceforth referred to as T2; (iii) the application of OWS alone at $100 \%$ of the dose based on the amount of $\mathrm{N}$ in the OWS per crop per season, henceforth referred to as T3; (iv) a combination of $75 \% \mathrm{MF}(\mathrm{T} 2)+25 \%$ OWS (T3), henceforth referred to as T4; (v) a combination of $50 \% \mathrm{MF}(\mathrm{T} 2)+50 \%$ OWS (T3), henceforth referred to as $\mathrm{T} 5$; and (vi) a combination of $25 \% \mathrm{MF}(\mathrm{T} 2)+75 \%$ OWS (T3), henceforth referred to as T6.

Each experimental unit was $40 \mathrm{~m}^{2}, 8 \mathrm{~m}$ long and 5 $\mathrm{m}$ wide. The experiment began on November 20, 2009, and soil samples for $\mathrm{C}$ analysis were collected after the summer harvest in May 2012, with the total C recorded after five crops. The crop rotation in the study period occurred as follows: beans in the summer, wheat in the winter, soybeans in the summer, black oats in the winter, and corn in the summer. The treatments were always applied one day after sowing for each crop, the details of which have been provided in the description of the crops and management practices (Table 3 ).
Control of weeds, pests, and diseases and other crop management practices were performed according to the recommendations for each crop. The definition of the nutrient requirements for the fertilizer recommendation for all crops was based on the concentrations found in the soil analysis and on the needs of the crops according to the regional recommendations of the ABC Foundation. The amount of MF applied is shown in Table 4. In treatments T4, T5, and T6, the doses shown in Table 4 were reduced to 75, 50, and 25\% MF.

The nutritional content of the OWS applied in each treatment is shown in Table 5, and all crop seasons received the same amounts of the nutrients listed below. Treatments T4, T5, and T6 received, respectively, 25, 50, and $75 \%$ of the OWS dose applied to T3.

The quantity of OWS was defined based on the amount of $\mathrm{N}$ in the waste and adjusted for each combination of treatments. The annual input of $\mathrm{C}$ into the system through crop residue (roots and shoots) was measured through the cumulative grain yield for each treatment during the study period. The estimate for each treatment was based on the harvest index (HI), the root/shoot ratio, and the amount of $\mathrm{C}$ in each crop (SÁ et al., 2014; TIVET et al., 2013) as well as the amount of $\mathrm{C}$ in the OWS. Table 6 summarizes the $\mathrm{C}$ inputs derived from the dry matter and from the OWS for

Table 3 - Crop, variety, cultivar or hybrid, spacing, plant population, and dates of sowing and harvesting in the no-till system in the experimental area

\begin{tabular}{lccccc}
\hline \multicolumn{1}{c}{ Crop } & Variety & Row spacing $^{(1)}$ & Plant population & Sowing date & Harvest date \\
\hline Bean & Uirapuru & 45 & 280,000 plants ha $^{-1}$ & $11 / 20 / 2009$ & $02 / 27 / 2010$ \\
Wheat & Safira & 17 & 320 plants m $^{-2}$ & $07 / 06 / 2010$ & $11 / 20 / 2010$ \\
Soybean & BRS 246 RR & 45 & 400,000 plants ha $^{-1}$ & $12 / 04 / 2010$ & $04 / 15 / 2010$ \\
Oat & IAPAR 61 & $(3)$ & 350 plants m $^{-2}$ & $06 / 17 / 2011^{(2)}$ & $09 / 15 / 2011$ \\
Corn & 30F53H & 80 & 60,000 plants ha $^{-1}$ & $09 / 26 / 2011$ & $04 / 28 / 2012$ \\
\hline
\end{tabular}

${ }^{1}$ Row spacing in centimeters; ${ }^{2}$ Dry mass of black oats was collected; and ${ }^{3}$ Broadcast sowing of black oats

Table 4 - Amount of mineral fertilizer applied in treatment T2 (100\% MF) for each crop

\begin{tabular}{lccccc}
\hline \multirow{2}{*}{ Crop } & \multicolumn{3}{c}{ Fertilization on band aplication } & \multicolumn{2}{c}{ Fertilization on surface aplication } \\
\cline { 2 - 4 } & $\mathrm{N}$ & $\mathrm{P}_{2} \mathrm{O}_{5}$ & $\mathrm{~K}_{2} \mathrm{O}$ & $\mathrm{N}$ \\
\hline - & 30 & 60 & 30 & $\mathrm{~K}_{2} \mathrm{O}$ \\
\hline Wean & 25 & 50 & 50 & 40 & - \\
Soybean & 6 & 60 & 60 & -5 & - \\
Oat & 21 & 51 & 18 & - & - \\
Corn & 30 & 85 & 25 & 108 & 36 \\
\hline
\end{tabular}


Table 5 - Amounts of nutrients supplied via the OWS in each treatment by crop season for each crop residues

\begin{tabular}{lcccccc}
\hline \multicolumn{1}{c}{ Nutrient } & $\mathrm{T} 1^{(1)}$ & $\mathrm{T} 2^{(2)}$ & $\mathrm{T}^{(3)}$ & $\mathrm{T}^{(4)}$ & $\mathrm{T}^{(5)}$ & $\mathrm{T}^{(6)}$ \\
\hline $\mathrm{N}$ & - & - & 94.4 & 23.6 & 47.2 & 70.8 \\
$\mathrm{P}$ & - & - & 21.0 & 5.25 & 10.5 & 15.8 \\
$\mathrm{~K}$ & - & - & 19.0 & 4.75 & 9.50 & 14.3 \\
\hline
\end{tabular}

${ }^{1} \mathrm{~T} 1=$ General control (without MF and OWS); ${ }^{2} \mathrm{~T} 2=100 \% \mathrm{MF} ;{ }^{3}: \mathrm{T} 3=100 \% \mathrm{OWS} ;{ }^{4} \mathrm{~T} 4=75 \% \mathrm{MF}+25 \% \mathrm{OWS} ;{ }^{5} \mathrm{~T} 5=50 \% \mathrm{MF}+50 \%$ OWS; and ${ }^{6} \mathrm{~T} 6=25 \% \mathrm{MF}+75 \%$ OWS

Table 6 - Carbon (C) inputs derived from plant biomass (shoots and roots) and organic waste from slaughterhouses (OWS) during the five crop seasons of the experiment

\begin{tabular}{|c|c|c|c|c|c|c|c|c|}
\hline Crops & Season & C-input & $\mathrm{T} 1^{(1)}$ & $\mathrm{T} 2^{(2)}$ & $\mathrm{T}^{(3)}$ & $\mathrm{T} 4^{(4)}$ & $\mathrm{T} 5^{(5)}$ & $\mathrm{T} 6^{(6)}$ \\
\hline \multirow{3}{*}{ Bean } & 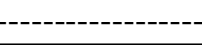 & - & 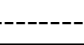 & $\mathrm{ha}^{-1}--$ & ------ & ------ & ------- & -------" \\
\hline & $2009 / 10^{(7)}$ & Crop residues & 0.98 & 1.02 & 0.78 & 1.30 & 1.53 & 1.61 \\
\hline & & OWS & & & 0.64 & 0.16 & 0.32 & 0.48 \\
\hline \multirow[t]{2}{*}{ Wheat } & $2010^{(7)}$ & Crop residues & 0.33 & 0.58 & 1.19 & 0.83 & 0.85 & 1.08 \\
\hline & & OWS & & & 0.64 & 0.16 & 0.32 & 0.48 \\
\hline \multirow[t]{2}{*}{ Soybean } & $2010 / 11^{(7)}$ & Crop residues & 0.91 & 1.08 & 1.65 & 1.19 & 1.40 & 1.46 \\
\hline & & OWS & & & 0.64 & 0.16 & 0.32 & 0.48 \\
\hline \multirow[t]{2}{*}{ Oat } & $2011^{(7)}$ & Crop residues & 0.91 & 2.38 & 2.70 & 2.02 & 2.68 & 2.18 \\
\hline & & OWS & & & 0.64 & 0.16 & 0.32 & 0.48 \\
\hline \multirow[t]{2}{*}{ Corn } & $2011 / 2012^{(7)}$ & Crop residues & 4.30 & 7.51 & 6.74 & 7.26 & 6.57 & 6.37 \\
\hline & & OWS & & & 0.64 & 0.16 & 0.32 & 0.48 \\
\hline TOTAL & & & 7.43 & 12.57 & 16.26 & 13.40 & 14.63 & 15.10 \\
\hline
\end{tabular}

${ }^{1} \mathrm{~T} 1=$ General control (without MF and OWS); ${ }^{2} \mathrm{~T} 2=100 \% \mathrm{MF} ;{ }^{3} \mathrm{~T} 3=100 \% \mathrm{OWS} ;{ }^{4} \mathrm{~T} 4=75 \% \mathrm{MF}+25 \% \mathrm{OWS} ;{ }^{5} \mathrm{~T} 5=50 \% \mathrm{MF}+50 \%$ OWS $;{ }^{6} \mathrm{~T} 6=25 \% \mathrm{MF}+75 \%$ OWS; and ${ }^{7}$ Crop year

each treatment during the study period, which was used as the basis for understanding the variation in the $\mathrm{C}$ stock.

\section{Collection and preparation of soil samples}

In May 2012, after the corn crop season, the soil samples were collected from the $0-5,5-10$, and $10-20 \mathrm{~cm}$ soil layers using an auger. The samples were oven dried at $40{ }^{\circ} \mathrm{C}$ until achieving constant weight and were then broken up and passed through a $2 \mathrm{~mm}$ sieve. Particle size analysis (sand, silt and clay) and the determination of the components of the soil exchange complex were performed on these samples.

\section{Particle-size fractionation of soil $\mathrm{C}$}

Particle-size fractionation of SOM was performed on the 2-mm sieved samples to separate the particulate carbon (POC) fraction, with a size between 53 and $2000 \mathrm{~m}$, and the mineral-bound organic carbon (MOC) fraction, i.e., smaller than $53 \mu \mathrm{m}(<53 \mu \mathrm{m})$. This procedure was performed by weighing $40 \mathrm{~g}$ of soil in a 1-L plastic bottle and adding $100 \mathrm{~mL}$ of deionized water and $0.75 \mathrm{~g}$ hexametaphosphate. Next, the samples were placed on a horizontal shaker (set to $100 \mathrm{rpm}$ ) to separate the fractions according to the method described by Feller (1994) and modified by Sá et al. (2001). After shaking, the soil was passed through a 5- $\mu \mathrm{m}$ sieve, and the material that was retained on

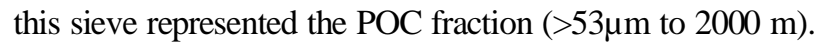
The material that passed through the sieve was placed in a beaker and represented the MOC fraction $(<53 \mu \mathrm{m})$.

\section{Determination of total organic $\mathbf{C}$ in the whole sample and particle-size fractions}

The total organic carbon (TOC) was determined in both the whole samples and in the POC and MOC fractions through the dry combustion method using a $\mathrm{C}$ and $\mathrm{N}$ elemental analyzer (TruSpec CN LECO® 2006, St. Joseph, USA), and the results were expressed in $\mathrm{C} \mathrm{kg}^{-1}$ of soil. 
The determinations of the labile fractions of carbon oxidized by permanganate (C-OXP) and extracted with hot water (C-HW) were performed on whole soil samples. The C-HW was extracted by the method adapted by Ghani, Dexter and Perrott (2003). In short, $3 \mathrm{~g}$ of soil was weighed into a $25-\mathrm{mL}$ tube to which $10 \mathrm{~mL}$ of deionized water was added. The mixture was stirred manually for 10 seconds to ensure complete suspension, and then the tubes were dried in an oven at $80{ }^{\circ} \mathrm{C}$ for 16 hours. After incubation, centrifugation was performed at $4000 \mathrm{rpm}$. Next, the supernatant was removed, and the C-HW was determined using wet oxidation following the modified method of Walkley and Black (1934) as described by Nelson et al. (1996).

The extraction of the C-OXP was based on the method of Tirol-Padre and Ladha (2004). In short, $10 \mathrm{~mL}$ of $60 \mathrm{mmol} \mathrm{L}^{-1}$ of potassium permanganate $\left(\mathrm{KMnO}_{4}\right)$ solution was added to the soil sample remaining in the $25-\mathrm{mL}$ tube after the hot water extraction. Then, the samples were placed on a tube shaker for 10 seconds, after which $2 \mathrm{~mL}$ of the supernatant was removed and transferred to a glass container. Next, $100 \mathrm{~mL}$ of deionized water was added before reading on a visible light spectrophotometer set to absorbance at $565 \mathrm{~nm}$.

\section{Calculation of the $\mathbf{C}$ stock in the whole samples and in the particle-size fractions}

The C stock was calculated for the whole samples in each layer sampled and in each particle-size fraction. The following formula was used: $\mathrm{stC}=(\mathrm{TOC} \times \mathrm{Ds} \times t) / 10$, where $\mathrm{stC}$ is the stock of total organic carbon in the soil at a given depth ( $\left.\mathrm{Mg} \mathrm{ha}^{-1}\right)$; COT is the total organic carbon content expressed in $\mathrm{g} \mathrm{kg}^{-1}$; Ds is the soil bulk density at each depth, expressed as $\mathrm{Mg} \mathrm{m}^{-3}$; and $t$ represents the thickness of the given layer expressed in $\mathrm{cm}$. Soil bulk density was determined using the volumetric ring method, following Blake and Hartge (1986). The mean Ds values were obtained by averaging three rings per experimental unit in three replicates for a total of 36 rings per sampled layer. The means, with respective standard deviations shown in parentheses, were $1.26( \pm 0.12), 1.40$ $( \pm 0.10), 1.37( \pm 0.07)$, and $1.35( \pm 0.05) \mathrm{Mg} \mathrm{m}^{-3}$ for the $0-5,5-10,10-20$, and 0-20 cm layers, respectively.

The results for the content and the stock of TOC in the whole samples, the particle-size fractions, and the labile compartments of SOM were subjected to analysis of variance (ANOVA). The means that were significantly different by the F-test were compared using the LSD test at 5\% probability ( $\alpha=0.05)$ using SISVAR version 5.1 (FERREIRA, 2007).

\section{RESULTS AND DISCUSSION}

The results of the analysis of variance (Table 7) showed a significant response to the treatments in the stock of TOC, MOC, C-OXP, and C-HW ( $p<0.05$ and $<0.01$ ). There was a significant effect on the TOC and C-OXP contents in all of analyzed layers ( $\mathrm{p}<0.05$ for TOC and $\mathrm{p}<0.01$ for $\mathrm{C}-\mathrm{OXP})$.

Table 7 - ANOVA F values and coefficients of variation (CV) for the TOC content and stock of the soil and compartments in response to the use of mineral fertilizer and organic waste from slaughterhouses applied alone or in combination in a no-till system

\begin{tabular}{|c|c|c|c|c|c|c|c|c|c|c|}
\hline \multicolumn{11}{|c|}{ Source of variation of $\mathrm{C}$} \\
\hline \multirow{2}{*}{ Source of variation } & \multicolumn{6}{|c|}{ Content } & \multicolumn{4}{|c|}{ Stock } \\
\hline & $\mathrm{TOC}^{(1)}$ & $\mathrm{POC}^{(2)}$ & $\mathrm{MAOC}^{(3)}$ & $\mathrm{C}-\mathrm{OXP}{ }^{(4)}$ & $\mathrm{C}-\mathrm{HW}^{(5)}$ & TOC & POC & MAOC & C-OXP & C-HW \\
\hline \multicolumn{11}{|c|}{ 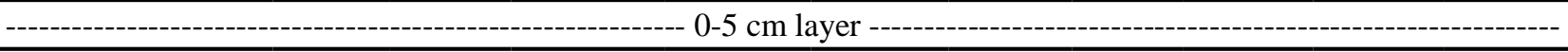 } \\
\hline Treatment & $0.71 *$ & $0.30^{\mathrm{ns}}$ & $1.64 *$ & $8.82 * *$ & $18.41 * *$ & $4.38^{*}$ & $0.30^{\mathrm{ns}}$ & $1.17 *$ & $3.22 *$ & $18.59 * *$ \\
\hline C.V.(\%) & 15.14 & 34.5 & 10.27 & 13.10 & 21.82 & 4.00 & 23.04 & 15.33 & 22.12 & 21.70 \\
\hline \multicolumn{11}{|c|}{ 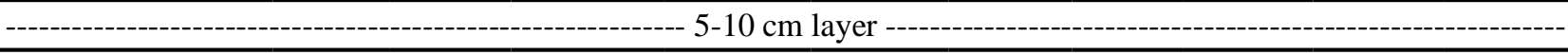 } \\
\hline Treatment & $1.14^{*}$ & $0.67^{\mathrm{ns}}$ & $0.43^{\text {ns }}$ & $12.28 * *$ & $22.91 * *$ & $0.75^{*}$ & $3.13^{*}$ & $0.56^{*}$ & $2.48^{*}$ & $29.91 * *$ \\
\hline C.V. $(\%)$ & 11.53 & 8.78 & 14.98 & 10.14 & 20.71 & 9.27 & 26.88 & 14.27 & 24.00 & 17.62 \\
\hline \multicolumn{11}{|c|}{ - } \\
\hline Treatment & $1.12 *$ & $0.77^{\mathrm{ns}}$ & $0.51^{\mathrm{ns}}$ & $5.80 * *$ & $13.11 * *$ & $1.91^{*}$ & $0.56^{\mathrm{ns}}$ & $0.18 *$ & $2.78 *$ & $13.04 * *$ \\
\hline C.V. $(\%)$ & 7.64 & 22.9 & 23.55 & 17.67 & 28.04 & 7.67 & 14.27 & 26.08 & 29.71 & 28.10 \\
\hline \multicolumn{11}{|c|}{ - } \\
\hline Treatment & & & & & & $5.23 * *$ & $1.70 *$ & $0.58^{\mathrm{ns}}$ & $3.37 *$ & $45.05 * *$ \\
\hline C.V.(\%) & & & & & & 3.65 & 6.79 & 14.20 & 23.25 & 14.26 \\
\hline
\end{tabular}

ns, non-significant; * Significant at 5\%; ** Significant at $1 \% ;{ }^{1}$ TOC - Total organic carbon; ${ }^{2}$ POC - Particulate organic carbon; ${ }^{3}$ MOC - Mineralbound organic carbon; ${ }^{4} \mathrm{C}$-OXP - Carbon oxidized by permanganate; and ${ }^{5} \mathrm{C}$-HW Carbon extracted by hot water 
There was only a significant difference in the interaction between the POC content and stock in the $5-10 \mathrm{~cm}$ layer in response to the applied treatments.

The greater TOC content and stock in the $0-5 \mathrm{~cm}$ layer and the greater TOC stock in the $0-20 \mathrm{~cm}$ layer caused by the combination of $50 \% \mathrm{MF}+50 \%$ OWS (Table 8) emphasizes the treatment response of the biomass and root systems of the plants, resulting in improved structure. The contribution of the root system to $\mathrm{C}$ accumulation was well described by Wander and Yang (2000) and is likely due to the lower rate of decomposition of this structure compared with the shoots (BALESDENT; MARIOTTI, 1996). In addition to the results of Wander and Yang (2000), Balesdent and Mariotti (1996), Rasse, Rumpel and Dignac (2005) evaluated the results of numerous studies and concluded that the $\mathrm{C}$ derived from the roots remains in the soil 2.4 times longer than the $\mathrm{C}$ from the shoots due to the presence of organic compounds with longer residence times and greater stability in the soil.

In sugarcane crops, Andrade, Oliveira and Cerri (2005) applied biosolids derived from the treatment of sewage sludge and found greater increases in TOC only after the second year of application. Successive applications generated increasing increments over time. In the present study, the TOC gains in the $\mathrm{C}$ stock that accumulated in the $0-20 \mathrm{~cm}$ layer responded to the application of the different treatments (smaller stocks were observed in the control and greater stocks in the treatments with some form of fertilization), indicating a progressive trend of $\mathrm{C}$ accumulation (Table 8 ). At issue is the determination of the inflection point of the curve and the beginning of $\mathrm{C}$ stabilization in this system with a continuous supply of OWS.
The MOC and POC stocks were affected by the treatments (Table 9). The combination of $50 \% \mathrm{MF}+50 \%$ OWS (T5) resulted in greater migration of $\mathrm{C}$ from POC to MOC in the $0-5,10-20$, and $0-20 \mathrm{~cm}$ layers. Linear relationships have been reported between the input of biomass-C and $\mathrm{C}$ stocks in tropical and subtropical climates (BAYER; MIELNICZUK; MARTIN-NETO, 2000; BAYER et al., 2006; SÁ et al., 2001; SÁ et al., 2014).

In this study, we emphasize that the largest POC and MOC stocks occurred in treatments that received MF and OWS in combination, demonstrating a relationship between these fractions and the productive response of crops in these systems due to the promotion of a greater return of biomass from shoots and roots to the soil (LEITE et al., 2003). In contrast, the greatest concentration of labile carbon has been found in the surface layer and in no-till systems and has also shown a strong linear relationship due to greater biomass production (ROSSI, et al., 2012; SÁ et al., 2014; TIVET et al., 2013).

Carbon extracted by hot water $(\mathrm{C}-\mathrm{HW})$ and carbon oxidized by permanganate $(\mathrm{C}-\mathrm{OXP})$ are part of the soil $\mathrm{C}$ fraction with high lability and are influenced by management systems, particularly those that supply organic material to the soil (BAYER et al., 2002). The content and stock of the labile fractions (C-OXP and $\mathrm{C}-\mathrm{HW}$ ) significantly increased in all layers evaluated with OWS applied alone or in combination with MF (Table 10). This result supports the argument that OWS is generating a continuous $\mathrm{C}$ flow, which over time, is promoting the migration of $\mathrm{C}$ to the most stable compartment, thereby contributing to the increase in TOC (SÁ et al., 2009; SÁ et al., 2014; TIVET et al., 2013) shown in Table 6.

Table 8 - Total organic C (TOC) content and stock in response to the use of mineral fertilizer and organic waste from slaughterhouses applied alone or in combination under a no-till system

\begin{tabular}{|c|c|c|c|c|c|c|}
\hline \multirow{2}{*}{ Layer $(\mathrm{cm})$} & \multicolumn{6}{|c|}{ Treatments } \\
\hline & $\mathrm{T} 1^{(1)}$ & $\mathrm{T} 2^{(2)}$ & $\mathrm{T}^{(3)}$ & $\mathrm{T} 4^{(4)}$ & $\mathrm{T}^{(5)}$ & $\mathrm{T}^{(6)}$ \\
\hline & \multicolumn{6}{|c|}{ TOC Content, $\mathrm{g} \mathrm{kg}^{-1}$} \\
\hline $0-5$ & $18.16 \mathrm{~d}$ & $14.53 \mathrm{e}$ & $19.87 \mathrm{c}$ & $27.20 \mathrm{~b}$ & $29.50 \mathrm{a}$ & $26.63 \mathrm{~b}$ \\
\hline $5-10$ & $12.43 \mathrm{~b}$ & $14.52 \mathrm{ab}$ & $13.50 \mathrm{ab}$ & $13.20 \mathrm{ab}$ & $14.46 \mathrm{ab}$ & $15.50 \mathrm{a}$ \\
\hline \multirow[t]{2}{*}{$10-20$} & $11.63 \mathrm{~b}$ & $13.27 \mathrm{ab}$ & $12.53 \mathrm{ab}$ & $12.63 \mathrm{ab}$ & $14.30 \mathrm{a}$ & $13.17 \mathrm{ab}$ \\
\hline & \multicolumn{6}{|c|}{ TOC Stock, Mg ha-1 } \\
\hline $0-5$ & $11.45 \mathrm{~d}$ & $9.15 \mathrm{e}$ & $12.52 \mathrm{c}$ & $17.13 \mathrm{~b}$ & $18.59 \mathrm{a}$ & $16.78 \mathrm{~b}$ \\
\hline $5-10$ & $8.70 \mathrm{~b}$ & $10.17 \mathrm{ab}$ & $9.45 \mathrm{ab}$ & $9.24 \mathrm{ab}$ & $10.13 \mathrm{ab}$ & $10.85 \mathrm{a}$ \\
\hline $10-20$ & $15.94 \mathrm{~b}$ & $18.18 \mathrm{ab}$ & $17.17 \mathrm{ab}$ & $17.31 \mathrm{ab}$ & $19.59 \mathrm{a}$ & $18.04 \mathrm{ab}$ \\
\hline $0-20$ & 36.09 bc & $37.50 \mathrm{bc}$ & $39.14 \mathrm{~b}$ & $43.67 \mathrm{~b}$ & $48.31 \mathrm{a}$ & $45.66 \mathrm{ab}$ \\
\hline
\end{tabular}

${ }^{1} \mathrm{~T} 1=$ General control (without MF and OWS); ${ }^{2} \mathrm{~T} 2=100 \% \mathrm{MF} ;{ }^{3} \mathrm{~T} 3=100 \% \mathrm{OWS} ;{ }^{4} \mathrm{~T} 4=75 \% \mathrm{MF}+25 \% \mathrm{OWS} ;{ }^{5} \mathrm{~T} 5=50 \% \mathrm{MF}+50 \%$ OWS; and ${ }^{6} \mathrm{~T} 6=25 \% \mathrm{MF}+75 \%$ OWS. Means with the same letters in the same row do not differ from each other by the LSD test at $5 \%$. ns - nonsignificant by the F-test at $5 \%$ 
Table 9 - $\mathrm{C}$ content and stock in the particulate (POC) and mineral-associate organic C (MAOC) compartment in response to the use of mineral fertilizer and organic waste from slaughterhouses applied alone or in combination under a no-till system

\begin{tabular}{|c|c|c|c|c|c|c|}
\hline \multirow{2}{*}{ Layer (cm) } & \multicolumn{6}{|c|}{ Treatments } \\
\hline & $\mathrm{T}^{(1)}$ & $\mathrm{T} 2^{(2)}$ & $\mathrm{T}^{(3)}$ & $\mathrm{T} 4^{(4)}$ & $\mathrm{T}^{(5)}$ & T6(6) \\
\hline & \multicolumn{6}{|c|}{ POC Content, $\mathrm{g} \mathrm{kg}^{-1}$} \\
\hline $0-5$ & $5.00^{\mathrm{ns}}$ & 5.16 & 5.98 & 5.42 & 6.28 & 4.76 \\
\hline $5-10$ & $2.96^{\mathrm{ns}}$ & 2.66 & 2.79 & 2.67 & 2.83 & 2.71 \\
\hline \multirow[t]{2}{*}{$10-20$} & $2.80^{\text {ns }}$ & 2.68 & 2.60 & 2.50 & 3.37 & 2.57 \\
\hline & \multicolumn{6}{|c|}{ MOC Content, $\mathrm{g} \mathrm{kg}^{-1}$} \\
\hline $0-5$ & $50.00^{\mathrm{ns}}$ & 44.73 & 49.70 & 49.27 & 52.53 & 44.73 \\
\hline $5-10$ & $38.53^{\text {ns }}$ & 37.07 & 35.90 & 39.30 & 40.13 & 37.87 \\
\hline \multirow[t]{2}{*}{$10-20$} & $35.00^{\mathrm{ns}}$ & 24.20 & 33.83 & 36.97 & 41.93 & 35.73 \\
\hline & \multicolumn{6}{|c|}{ POC Stock, $\mathrm{Mg} \mathrm{ha}^{-1}$} \\
\hline $0-5$ & $2.03 \mathrm{ab}$ & $2.18 \mathrm{a}$ & $2.04 \mathrm{ab}$ & $2.13 \mathrm{ab}$ & $1.75 \mathrm{ab}$ & $1.39 \mathrm{~b}$ \\
\hline $5-10$ & $1.17 \mathrm{bc}$ & $1.06 \mathrm{c}$ & $1.28 \mathrm{bc}$ & $1.19 \mathrm{bc}$ & $1.98 \mathrm{a}$ & $1.79 \mathrm{ab}$ \\
\hline $10-20$ & $2.15^{\mathrm{ns}}$ & 2.29 & 2.20 & 2.10 & 2.29 & 2.97 \\
\hline \multirow[t]{2}{*}{$0-20$} & $5.35^{\text {ns }}$ & 5.53 & 5.52 & 5.42 & 6.02 & 6.15 \\
\hline & \multicolumn{6}{|c|}{ MAOC Stock, Mg ha-1 } \\
\hline $0-5$ & $9.41 \mathrm{bc}$ & $6.97 \mathrm{c}$ & $10.48 \mathrm{abc}$ & $15.00 \mathrm{ab}$ & $16.84 \mathrm{a}$ & $15.39 \mathrm{ab}$ \\
\hline $5-10$ & $7.54^{\mathrm{ns}}$ & 9.11 & 8.17 & 8.05 & 8.14 & 9.06 \\
\hline $10-20$ & $13.79 \mathrm{~b}$ & $15.89 \mathrm{ab}$ & $14.97 \mathrm{ab}$ & $15.21 \mathrm{ab}$ & $17.31 \mathrm{a}$ & $15.07 \mathrm{ab}$ \\
\hline $0-20$ & $30.74 \mathrm{c}$ & $31.97 \mathrm{bc}$ & $33.62 \mathrm{bc}$ & $38.25 \mathrm{abc}$ & $42.29 \mathrm{a}$ & $39.51 \mathrm{ab}$ \\
\hline
\end{tabular}

${ }^{1} \mathrm{~T} 1$ = General control (without MF and OWS); ${ }^{2} \mathrm{~T} 2=100 \% \mathrm{MF} ;{ }^{3} \mathrm{~T} 3=100 \%$ OWS; ${ }^{4} \mathrm{~T} 4=75 \% \mathrm{MF}+25 \%$ OWS; ${ }^{5} \mathrm{~T} 5=50 \% \mathrm{MF}+50 \%$ OWS; and ${ }^{6} \mathrm{~T} 6=25 \% \mathrm{MF}+75 \%$ OWS. Means with the same letters in the same row do not differ from each other by the LSD test at $5 \%$. ns - non-significant by the F-test at $5 \%$

This study also found a short-term increase in labile forms (C-POX and C-HW) as a result of applying the combination of $50 \% \mathrm{MF}$ and $50 \%$ OWS, which stimulated biological activity in the soil and generated a continuous $\mathrm{C}$ flow in the system (SÁ; LAL, 2009). Consequently, adding decomposing organic materials promotes greater soil aggregation (SU et al., 2006) and better protection of intra-aggregate C (TIVET et al., 2013).

The statistically significant increase in C-OXP and C$\mathrm{HW}$ in response to the use of OWS in combination with MF (Table 10) indicates that the increase in TOC is being supplied by the labile fraction. The C-HW stock, which represents much of the $\mathrm{C}$ bound to microbial biomass, was greater in the treatments with combined MF and OWS, showing that it is the main component of a proposed continuous $\mathrm{C}$ flow. The cumulative stock in the $0-20 \mathrm{~cm}$ layer in T6 (Table 10) was $4.07 \mathrm{Mg} \mathrm{ha}^{-1}$ and $3.56 \mathrm{Mg} \mathrm{ha}^{-1}$ greater than that of the general control (T1) and that of T2 (100\% MF), respectively. The increase in this compartment indicates that the conditions are favorable for increasing the soil microbial activity, which provides the support for the transfer of new $\mathrm{C}$ to more stable forms bound to the clay fraction (BLAIR; CROCKER, 2000; SIX et al., 2006; TIVET et al., 2013).

The C-HW content decreased with increasing depth of the sampled layers in the soil profile, demonstrating that stratification in the soil profile (Table 10) is a natural process. Although this fact has been well reported in no-till systems (BRIEDIS et al., 2012; FERREIRA et al., 2013; FIGUEIREDO et al., 2007; SÁ; LAL, 2009;), the effect is even more pronounced in the present experiment because the types of organic compounds in OWS are easily oxidized and serve as an energy source for the activity of the microbial community.

In summary, the $\mathrm{C}$ input from waste on the soil surface was greater in treatments with the application of OWS in combination with MF and lower in the general control and in the treatment with MF alone. This input promoted soil microbial activity and stimulated a continuous organic matter mineralization process (BALESDENT et al., 1998). As a result, a continuous flow of $\mathrm{C}$ was generated, which supplied the labile fractions and supported the migration to more stable 
Table 10 - Content and stock of C oxidizable by potassium permanganate (C-OXP) and hot water (C-HW) in response to the use of mineral fertilizer and organic residue from slaughterhouses applied alone or in combination under a no-till system

\begin{tabular}{|c|c|c|c|c|c|c|}
\hline \multirow{2}{*}{ Layer $(\mathrm{cm})$} & \multicolumn{6}{|c|}{ Treatments } \\
\hline & $\mathrm{T} 1^{(1)}$ & $\mathrm{T} 2^{(2)}$ & $\mathrm{T}^{(3)}$ & $\mathrm{T} 4^{(4)}$ & $\mathrm{T}^{(5)}$ & T6 $6^{(6)}$ \\
\hline & \multicolumn{6}{|c|}{ C-OXP Content, $\mathrm{g} \mathrm{kg}^{-1}$} \\
\hline $0-5$ & $1.29 \mathrm{~b}$ & $2.34 \mathrm{a}$ & $2.74 \mathrm{a}$ & $2.49 \mathrm{a}$ & $2.72 \mathrm{a}$ & $2.86 \mathrm{a}$ \\
\hline $5-10$ & $0.89 \mathrm{c}$ & $1.71 \mathrm{ab}$ & $1.74 \mathrm{ab}$ & $1.54 \mathrm{~b}$ & $1.89 \mathrm{a}$ & $1.80 \mathrm{ab}$ \\
\hline \multirow[t]{2}{*}{$10-20$} & $0.67 \mathrm{a}$ & $1.61 \mathrm{~b}$ & $1.43 \mathrm{~b}$ & $1.28 \mathrm{~b}$ & $1.66 \mathrm{~b}$ & $1.68 \mathrm{~b}$ \\
\hline & \multicolumn{6}{|c|}{ C-HW Content, $\mathrm{g} \mathrm{kg}^{-1}$} \\
\hline $0-5$ & $0.42 \mathrm{c}$ & $0.67 \mathrm{c}$ & $1.29 \mathrm{~b}$ & $2.07 \mathrm{a}$ & $2.07 \mathrm{a}$ & $2.33 \mathrm{a}$ \\
\hline $5-10$ & $0.50 \mathrm{~b}$ & $0.69 \mathrm{~b}$ & $0.69 \mathrm{~b}$ & $1.93 \mathrm{a}$ & $2.02 \mathrm{a}$ & $1.95 \mathrm{a}$ \\
\hline \multirow[t]{2}{*}{$10-20$} & $0.51 \mathrm{~b}$ & $0.67 \mathrm{~b}$ & $0.57 \mathrm{~b}$ & $1.54 \mathrm{a}$ & $1.95 \mathrm{a}$ & $2.03 \mathrm{a}$ \\
\hline & \multicolumn{6}{|c|}{ C-OXP Stock, Mg ha' } \\
\hline $0-5$ & $0.81 \mathrm{~b}$ & $1.48 \mathrm{a}$ & $1.70 \mathrm{a}$ & $1.57 \mathrm{a}$ & $1.71 \mathrm{a}$ & $1.80 \mathrm{a}$ \\
\hline $5-10$ & $0.62 \mathrm{~b}$ & $1.20 \mathrm{a}$ & $1.22 \mathrm{a}$ & $1.08 \mathrm{a}$ & $1.33 \mathrm{a}$ & $1.26 \mathrm{a}$ \\
\hline $10-20$ & $0.91 \mathrm{~b}$ & $2.21 \mathrm{a}$ & $1.95 \mathrm{a}$ & $1.75 \mathrm{a}$ & $2.28 \mathrm{a}$ & $2.30 \mathrm{a}$ \\
\hline \multirow[t]{2}{*}{$0-20$} & $2.35 \mathrm{~b}$ & $4.88 \mathrm{a}$ & $4.90 \mathrm{a}$ & $4.40 \mathrm{a}$ & $5.32 \mathrm{a}$ & $5.36 \mathrm{a}$ \\
\hline & \multicolumn{6}{|c|}{ C-HW Stock, Mg ha-1 } \\
\hline $0-5$ & $0.26 \mathrm{c}$ & $0.42 \mathrm{c}$ & $0.81 \mathrm{~b}$ & $1.31 \mathrm{a}$ & $1.30 \mathrm{a}$ & $1.47 \mathrm{a}$ \\
\hline 5-10 & $0.35 \mathrm{~b}$ & $0.48 \mathrm{~b}$ & $0.48 \mathrm{~b}$ & $1.35 \mathrm{a}$ & $1.41 \mathrm{a}$ & $1.37 \mathrm{a}$ \\
\hline $10-20$ & $0.70 \mathrm{~b}$ & $0.91 \mathrm{~b}$ & $0.79 \mathrm{~b}$ & $2.10 \mathrm{a}$ & $2.67 \mathrm{a}$ & $2.78 \mathrm{a}$ \\
\hline $0-20$ & $1.31 \mathrm{~b}$ & $1.82 \mathrm{~b}$ & $2.08 \mathrm{~b}$ & $4.76 \mathrm{a}$ & $5.38 \mathrm{a}$ & $5.61 \mathrm{a}$ \\
\hline
\end{tabular}

${ }^{1} \mathrm{~T} 1=$ General control (without MF and OWS); ${ }^{2} \mathrm{~T} 2=100 \% \mathrm{MF} ;{ }^{3} \mathrm{~T} 3=100 \% \mathrm{OWS} ;{ }^{4} \mathrm{~T} 4=75 \% \mathrm{MF}+25 \% \mathrm{OWS} ;{ }^{5} \mathrm{~T} 5=50 \% \mathrm{MF}+50 \% \mathrm{OWS} ;$ and ${ }^{6} \mathrm{~T} 6=25 \%$ $\mathrm{MF}+75 \%$ OWS. Means with the same letters in the same row do not differ from each other by the LSD test at 5\%, ns - non-significant by the F-test at 5\%

forms of SOM. The use of OWS alone or in combination with MF was shown to be an alternative not only for recycling nutrients but also for increasing the soil capacity and accumulating $\mathrm{C}$ as well as for contributing to the mitigation of some $\mathrm{CO}_{2}$ emissions resulting from grain production.

The TOC, C-POX, and C-HW stocks in the $0-20 \mathrm{~cm}$ layer yielded significant gains with the $\mathrm{C}$ supplied (Tables 8 and 10). This difference may be the result of the increased root biomass due to the increased cumulative grain production, thus generating more plant biomass (Table 6). The contribution of biomass from shoots and roots, combined with no-till, may contribute to the increase in the soil organic matter (SOM) content and carbon (C) stocks (SÁ et al., 2014).

\section{CONCLUSIONS}

The application of OWS alone or in combination with MF promoted gains in the labile forms of $\mathrm{C}$. The increase in the stock of these fractions promoted the generation of a $\mathrm{C}$ flow that supported the increase in TOC for the treatment where
OWS was applied in combination with 50\% MF. The use of OWS is an option that can potentially mitigate $\mathrm{C}$ emissions, with a consequent positive environmental impact.

\section{REFERENCES}

ASSOCIAÇÃO BRASILEIRA INDÚSTRIA PRODUTORA E EXPORTADORA DE CARNE SUÍNA. RelatórioABIPECS 2010. Disponível em: <www.abipecs.org.br>. Acesso em: 19 dez. 2013.

ANDRADE, C. A.; OLIVEIRA, C.; CERRI, C. C. Organic matter quality and carbon and nitrogen stocks in an Oxisol treated with biossolids and cultivated with eucalyptus. Revista Brasileira de Ciência do Solo, v. 29, n. 5, p. 803-816, 2005.

BALESDENT, J. et al. The dynamics of carbon in particle-size fractions of soil in a forest-cultivation sequence. Plant and Soil, v. 201, n. 1, p. 49-57, 1998.

BALESDENT, J.; MARIOTTI, A. 1996. Measurement of soil organic matter turnover using $13 \mathrm{C}$ natural abundance. In: Mass Spectrometry of Soils (eds BOUTTON, T. W.; YAMASAKI S. I.), p. 83ะ111, 1996. 
BANGER, K., et al. Soil organic carbon fractions after 16years of applications of fertilizers and organic manure in a Typic Rhodalfs in semi-arid tropics. Nutrient Cycling in Agroecosystems, v. 3, n. 86, p. 391-399, 2010.

BAYER, C. et al. Carbon sequestration in two Brazilian Cerrado soils under no-till. Soil and Tillage Research, v. 86, n. 2, p. 237-245, 2006.

BAYER, C. et al. Tillage and cropping system effects on soil humic acid characteristics as determined by electron spin resonance and fluorescence spectroscopies. Geoderma, v. 105, n. 1/2, p. 81-92, 2002.

BAYER, C. et al. Changes in soil organic matter fractions under subtropical no-till cropping systems. Soil Science Society of America Journal, v.65, p.1473-1478, 2001.

BAYER, C.; MIELNICZUK, J.; MARTIN-NETO, L. Efeito de sistemas de preparo e de cultura na dinâmica da matéria orgânica e na mitigação das emissões de $\mathrm{CO}_{2}$. Revista Brasileira de Ciência do Solo, v. 24, n. 3, p. 599-607, 2000.

BELLAVER,C.Inter-relaçõesdo beneficiamento dos subprodutos do abate com a produção animal, ambiente e economia no Brasil. In: WORKSHOP SOBRE SUBPRODUTOS DE ORIGEM ANIMAL NA ALIMENTAÇÃO. 2003. São Paulo. Anais... Concórdia, SC: Embrapa Suínos e Aves, 2003. v. 2, p. 1-7.

BLAIR, N.; CROCKER, G. J. Crop rotation effects on soil carbon and physical fertility of two Australian soils. Soil Research, v. 38, n. 1, p. 71-84, 2000.

BLAKE, G. R.; HARTGE, K. H. Bulk density. KLUTE, A. (Ed.). Methods of soil analysis. Part 1.Physical and mineralogical methods. 2nd. ed. Madison: Wisconsin, American Society of Agronomy, Soil Science Society of America, 1986. p. 363-375. (Agronomy Series, 5).

BRIEDIS, C. et al. Particulate soil organic carbon and stratification ratio increases in response to crop residue decomposition under no-till. Revista Brasileira de Ciência do Solo, v. 36, n. 5, p. 1483-1490, 2012.

CHRISTENSEN B. T. Physical fractionation of soil and organic matter in primary particle size and density separates. Advances in Soil Science. In press, 1992.

FOOD AND AGRICULTURE ORGANIZATION OF THE UNITED NATIONS. Statistical Yearbook 2013. Disponível em <http://faostat3.fao.org/faostat-gateway/go/to/home/E > Consultado em 12/04/2013.

FELLER, C. Lá matiére organique dansle sols tropicaux à argiles 1:1. Recherche de compartiments organiques fonctionnels.Uneap proche granulométrique. Thèse (Doctorate ès Science) - University of Strasbourg (ULP), Strasbourg, France, 1994. p. 393.

FERREIRA, D. F. SISVAR 5.0. Lavras: Universidade Federal de Lavras, 2007.

FIGUEIREDO, C. C. D. et al. Carbono e nitrogênio da biomassa microbiana em resposta a diferentes sistemas de manejo em um Latossolo Vermelho no Cerrado. Revista Brasileira de Ciência do Solo, v. 31, n. 3, p. 551-562, 2007.
GHANI, A.; DEXTER, M.; PERROTT, K. W. Hot-water extractable carbon in soils: a sensitive measurement for determining impacts of fertilization, grazing and cultivation. Soil Biology and Biochemistry, v. 35, n. 9, p. 1231-1243, 2003.

INSTITUTO BRASILEIRO DE GEOGRAFIA E ESTATÍSTICA. Banco de Dados Agregados. 2010. Disponível em: <http://www.sidra.ibge.gov.br/bda/territorio/ default. asp? $\mathrm{z}=\mathrm{t} \& \mathrm{o}=4 \& \mathrm{i}=\mathrm{P}>$. Acesso em: $27 \mathrm{dez} .2013$.

INSTITUTO AGRONÔMICO DO PARANÁ. Cartas climáticas do Paraná. Disponível em: <http://www.iapar.br/modules/conteudo/ conteudo.php?conteudo=856>. Acesso em: 27 jan. 2013.

JIANG, H. M. et al. Soil carbon pool and effects of soil fertility in seeded alfalfa fields on the semi-arid Loess Plateau in China. Soil Biology and Biochemistry, v. 38, n. 8, p. 2350-2358, 2006.

LEITE, L. F. C. et al. Estoques totais de carbono orgânico e seus compartimentos em Argissolo sob floresta e sob milho cultivado com adubação mineral e orgânica. Revista Brasileira de Ciência do Solo, v. 27, n. 5, p. 821-832, 2003.

NELSON, D. W. et al. Total carbon, organic carbon, and organic matter. In: Methods of soil analysis.1996. p. 961-1010. Part 3-chemical methods.

NOGUEIRA, N. O. et al. Influência da aplicação de dois resíduos industriais nas propriedades químicas de dois solos cultivados com café arábica. Revista Ciência Agronômica, v. 43, n. 1, p. 11-21, 2012.

RASSE, D. P.; RUMPEL, C.; DIGNAC, M. F. Is soil carbon mostly root carbon? Mechanisms for a specific stabilization. Plant and Soil, v. 269, n. 1/2, p. 341-356, 2005.

ROSSI, C. Q. et al. Frações lábeis da matéria orgânica em sistema de cultivo com palha de braquiária e sorgo. Revista Ciência Agronômica, v. 43, n. 1, p. 38-46, 2012.

RUDRAPPA, L. et al. Long-term manuring and Fertilization effects on soil organic carbon pools in a Typic Haplustept of semiarid sub-tropical India. Soil and Tillage Research, v. 88, n. 1/2, p. 180-192, 2006.

SÁ, J. C. M. et al. Long-term tillage systems impacts on soil C dynamics, soil resilience and agronomic productivity of a Brazilian Oxisol. Soil and Tillage Research. v. 136, p. 38-50, 2014.

SÁ, J. C. M. et al. Organic matter dynamics and carbon sequestration rates for a tillage chronosequence in a Brazilian Oxisol. Soil Science Society Americam Journal, v.65, p. 14861499, 2001.

SÁ, J. C. M.; LAL, R. Stratification ratio of soil organic matter pools as an indicator of carbon sequestration in a tillage chronosequence on a Brazilian Oxisol. Soil \& Tillage Research. v. 103, n. 1, p. 46-56, 2009.

SIX, J. et al. Bacterial and fungal contributions to carbon sequestration in agroecosystems. Soil Science Society of America Journal. v. 70, n. 2, p. 555-569, 2006.

SU, Y. Z. et al. Long-term effect of fertilizer and manure application on soil-carbon sequestration and soil fertility 
under the wheat-wheat-maize cropping system in northwest China. Nutrient Cycling in Agroecosystems, v. 75, n. 1-3, p. 285-295, 2006.

TIVET, F. E. et al. Aggregate C depletion by plowing and its restoration by diverse biomass-C inputs under no-till in sub-tropical and tropical regions of Brazil. Soil and Tillage Research, v. 126, p. 203-218, 2013.
UNITED STATES DEPARTMENT OF AGRICULTURE. Keys to Soil Taxonomy. 11 ed. Washington, DC: Natural Resources Conservation Service, 2010. 338 p.

WANDER, M. M., YANG, X. M. Influence of tillage on the dynamics of loose- and occluded-particulate and humified organic matter fractions. Soil Biologic Biocheministry, n. 32, p. 1151-1160, 2000. 